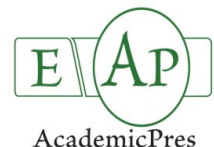

\title{
Preliminary Phytochemical Analysis and Antioxidant, Antibacterial Activities of Crocus alatavicus from Kazakhstan
}

\author{
Dariya SATYBALDIYEVA ${ }^{1 *}$, Valentina MURSALIYEVA², \\ Izbassar RAKHIMBAYEV ${ }^{2}$, Bolatkhan ZAYADAN $^{1}$, Ramazan MAMMADOV ${ }^{3}$ \\ ${ }^{1}$ Al-Farabi Kazakh National University, Faculty of Biology and Biotechnology, Al-Farabi 71/6, Almaty 050040, Kazakhstan; \\ dariya107@gmail.com (*correspondingauthor);zayadam.bolatkhan@kaznu.kz \\ 2Institute of Plant Biology and Biotechnology, Laboratory of Clonal Propagation, Timiryazev 45, Almaty050040, Kazakhstan; gen_mursal@mailru;rakhim_10@mail.ru \\ 3PamukkaleUniversity, Faculty ofSCience and Letters, Kinikli20017,Denizli,Tunkey;rmammad@yahoo.com
}

\begin{abstract}
Phytochemical analysis of $C$. alatavicus revealed the presence of phenols, flavonoids, anthocyanins, carotenoids, amino acids and carbohydrates. The flavonoid, amino acids and carotenoid contents were higher in aerial part $(1.50 \%, 7.49 \%$ and $9.78 \mathrm{mg} \%$, respectively) than in bulb $(0.43 \%, 3.88 \%$ and $0.91 \mathrm{mg} \%$, respectively). Total phenolic content (TPC), total antioxidant (TAA), 2.2-diphenyl-1-picrylhydrazyl (DPPH) radical scavenging and antibacterial activities of water, methanol, ethanol and dichloromethane extracts from aerial part and bulb were tested. TPC ranged from 13.63 to $72.29 \mathrm{mg}$ gallic acid equivalents (GAE)/g extract. The maximum TAA were observed in ethanol (61.34\%) and methanol extracts (46.13\%) from aerial part with a high TPC (72.29 and $62.37 \mathrm{mgGAE} / \mathrm{g}$ extract, respectively). Ethanol extracts from aerial part and bulb had good scavenger of DPPH radicals (65.5\% and 54.08\%, respectively) with an $\mathrm{IC}_{50} 387$ and $447 \mu \mathrm{g} / \mathrm{ml}$. Ethanol extract from aerial part was most effective against gram-positive bacterial strains $S$. aureus, B. subtilis and B. cereus. Biological activities of the extracts were correlated with the TPC. It can be deduced that ethanol and methnol extracts of $C$. alatavicus contains useful potent bioactive compounds with antioxidant and antimicrobial activities.
\end{abstract}

Keywords: bulb, DPPH-radical, extract, inhibition, phenolic

\section{Introduction}

The genus Crocus L. (Iridaceae) includes above 80 species occurring from Western Europe to western China (Harpke et al., 2013). Crocus species are highly valued as ornamental plants of their colourful flowers, horticultural varieties and industrial application (Saxena, 2015). Among the different species of Crocus, various biological activities and phytochemical constituents of $C$. sativus have been studied extensively because of saffron is widely used as a spice, food additive and as a textile dye or cosmetic ingredients and for treatment of some disease in many countries (Bhargava, 2011; Hosseinzadeh and Nassiri-Asl, 2013; Rezaee and Hosseinzadeh, 2013; Agnihotri, 2015). Antibacterial (Pintado et al., 2011; Agnihotri, 2015; Monte et al., 2015; Parray et al., 2015), antioxidant (Ferrara et al., 2014; Golmohammadi, 2014; Baba et al., 2015; Parray et al., 2015; Rahaiee et al., 2015), anti-mycobacterial (Hussain et al., 2014), cancer-suppressing (Samarghandian and Borji, 2014), antimutagenic, immunomodulating, antidepressant, antifungal
(Golmohammadi, 2014), antiparasitic activities (Monte et al., 2015) and analgesic effects (Simbar et al., 2015) of C. sativus have been reported. Anticancer (Chryssanthi et al., 2007), antimicrobial, antioxidant (Acar et al., 2010), cytotoxic (Tokgun et al., 2012) properties of the other Crocus species also have been reported.

C. alatavicus is an early spring ephemeral and geophyticgeocarpic species that grows in subalpine areas of the northern and western Tianshan Mountains (Baytenov, 2001; Zhang and Tan, 2009). It is an endemic of Kazakhstan flora belonging to the group of bulbous and tuberous plant. Wild habitat of this species is the Kora river middle flow, Koppal district, Taldykurgan region and South-East Kazakhstan. It widely distributed in Xinjiang that bordered by Mongolia, Kazakhstan, Uzbekistan and Kyrgyzstan (Saxena, 2015). The species mainly has potential in horticulture; it is the beautiful herb, highly rated for early blooming and easy cultivation (Ivaschenko, 2005). 
344

C. alatavicus is also interested as a source of naturally active substances that have many useful biological properties. Accumulation of the bioactive compounds is associated with the geophytic life-form of the plant and its ephemeral development cycle. Formation of underground storage corms contributes plant to survive adverse environment and proceeds the growth and reproducing of vegetative and generative organs (Kamenetsky and Okubo, 2013).

The species was used as spasmolytic, anti-inflammatory, bactericidal and antiviral agents in traditional Chinese medicine (Duke and Ayensu, 1985). The flowers were used as diuretic, for treatment of abdominal illness and to improve hormonal regulation of women (Egamberdieva et al., 2012). Dried stigmas are applied for colouring food products and impart flavour for them (Golovkyn et al., 2001).

Little is known about the phytochemical constituents of this species. The leaves contain ascorbic acid and the stigmas of flowers contain yellow pigment available for food colorant (Ivaschenko, 2005). Anthocyanins such as delphinidin 3-O- $\beta$ rutinoside and petunidin 3-O- $\beta$-rutinoside and flavonoids such as myricetin, quercetin, kaempferol have been investigated in flowers (Nørbæket al., 2002). It was reported that content of biological active substances in bulb of $C$. alatavicus depens on the vegetation period and weather conditions and it contributes the resistance of the plant to hostility and microflora during the growth (Kukushkina and Sedelnikova, 2010; Sedelnikova and Kukushkina, 2014). Studies addressing its biological activities are currently nonexistent. Hence, the aim of this study was preliminary phytochemical screening of different plant part and estimation of in vitro antioxidant, antimicrobial activities and total phenolic content of various extracts from aerial part and bulb of C. alatavicus.

\section{Materials and Methods}

\section{Plantmaterial}

Different parts (aerial part and bulbs) of $C$. alatavicus were collected from the natural environment of Almaty (Kazakhstan) in March, 2014. The Voucher specimen was deposited in the herbarium of Institute of Plant Biology and Biotechnology (Almaty, Kazakhstan). Aerial part and bulbs were cleaned, air dried in the shade at room temperature.

\section{Preparations of the extracts}

Powdered samples $(10 \mathrm{~g})$ were extracted with $100 \mathrm{ml}$ of different solvents (distilled water, $96 \%$ ethanol, $99 \%$ methanol and $99 \%$ dichloromethane) at $60{ }^{\circ} \mathrm{C}$ (methanol at $35^{\circ} \mathrm{C}$ ) for 6 hours in a water bath shaker. After the filtration with Watman No:1 filter paper the solvents were concentrated under vacuum $\left(48-49^{\circ} \mathrm{C}\right)$ by evaporating to dryness. All the extracts were stored at $-20^{\circ} \mathrm{C}$ until use.

\section{Phytochemical analysis}

Preliminary qualitative tests for screening of major biological active compounds in powdered aerial part and bulb were carried out according to the Harborne (1984). Standard quantitative analysis of flavonoid, carotenoids, carbohydrates and amino acid was used. For the determination of the total flavonoid content of the samples the aluminum chloride colorimetric method was used with quercetin as a standard. Free amino acid content by ninhydrin reaction was analysed. The phenol-sulfuric acid method was used for determination of carbohydrates in the samples. The total carotenoid content was determined by the standard spectrophotometric method.

\section{Determination of total phenolic content}

Total phenolic content (TPC) of the different extracts of $C$. alatavicus was determined with the Folin-Ciocalteu reagent according to the procedure reported by Türkoğlu et al. (2010), using gallic acid as a standard. The standard gallic acid curve was produced within the concentration range from 0.01 to $0.2 \mathrm{mg}$. The results were calculated by the equation based on the standard curve: $\mathrm{y}=1.1592 \mathrm{x}-0.0013, \mathrm{R}^{2}=0.9986$. TPC was expressed as $\mathrm{mg}$ of gallic acid equivalents (GAE) per $\mathrm{g}$ of dry extract.

\section{Determination of total antioxidant activity}

Total antioxidant activity (TAA) of the extracts was estimated by the $\beta$-carotene bleaching test following the procedure described by Wettasinghe and Shahidi (1999) with a slight modification. A stock solution of $\beta$-carotene-linoleic acid mixture was prepared as follows: $0.2 \mathrm{mg} \beta$-carotene was dissolved in $1 \mathrm{ml}$ of chloroform (HPLC grade), $20 \mu \mathrm{l}$ linoleic acid and 200 $\mu \mathrm{l}$ Tween 20 were added. Chloroform is completely evaporated at $40^{\circ} \mathrm{C}$ for $10 \mathrm{~min}$. Then, $50 \mathrm{ml}$ distilled water was added with a vigorous shaking. $4.8 \mathrm{ml}$ of this reaction mixture was dispensed to test tubes and $200 \mu \mathrm{l}$ portions of the extracts, prepared at 2 $\mathrm{mg} / \mathrm{ml}$ concentrations were added. The mixture is then gently mixed and incubated at $50^{\circ} \mathrm{C}$ for $2 \mathrm{~h}$. Absorbance of the sample was measured every $30 \mathrm{~min}$ for $2 \mathrm{~h}$ at $470 \mathrm{~nm}$ using a spectrophotometer. The same procedure was repeated with synthetic antioxidant butylated hydroxytoluene (BHT) as a positive control. TAA was calculated using the following equation: $A A=\left(1-A_{0}-A_{t} / A_{o}{ }^{\circ}-A_{t}{ }^{\circ}\right) \times 100$,

$\mathrm{AA}$ is an antioxidant activity, $\mathrm{A}_{0}$ and $\mathrm{A}_{0}{ }^{0}$ are the absorbance values measured at the initial incubation time of samples and control, respectively. While $A_{t}$ and $A_{t}^{0}$ are the absorbance values measured in the samples and control at $t=120 \mathrm{~min}$.

\section{DPPH radicalscavenging assay}

The hydrogen atoms or electron-donation ability of the extracts is measured from the bleaching of a purple-coloured methanol solution of DPPH according to the method Sanja et al. (2009). Stock solutions of the extracts were prepared at 1 $\mathrm{mg} / \mathrm{ml}$ concentration by dissolving in methanol and various concentrations $(100-500 \mu \mathrm{g} / \mathrm{ml})$ of the extracts were tested. Ascorbic acid (10, 15, 20, 25, $50 \mathrm{\mu g} / \mathrm{ml})$ and Trolox (10, 25, 50, $75 \mu \mathrm{g} / \mathrm{ml}$ ) were used as positive control. DPPH radical scavenging activity (\% antiradical activity) was calculated using the following equation: $\%$ antiradical activity $=\left(A_{0}-A_{1}\right) / A_{0} x$ $100, A_{0}$ is the absorbance of the control and $A_{1}$ is the absorbance of the extract/standard. A percent inhibition versus concentration curve was plotted and the amount of antioxidant necessary to decrease the initial DPPH concentration by $50 \%$

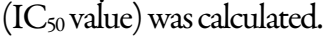

\section{Antimicrobial activity test}

Antibacterial activity of some extracts was determined by the disk diffusion method (Singh et al., 2002). Among the extracts obtained by polar solvents only water and ethanol extracts were tested for antibacterial activity. The extracts obtained by 
relatively nonpolar dichloromethane also were tested. Four strains of bacteria including gram-positive Staphylococcus aureus, Bacillus subtilis, Bacillus cereus and gram-negative Escherichia coli were used for tests. Sample solution were prepared by dissolving the dried extracts in their solvents (water, ethanol and dichloromethane) to give concentration of $1 \mathrm{mg} / \mathrm{ml} .25$ and 50 $\mu \mathrm{l}$ of the extract was impregnated into standard disks. Antibacterial agent kanamycin ( $1 \mathrm{mg} / \mathrm{ml} ; 20 \mu \mathrm{l} /$ disk, $)$ was used as a positive control and antimicrobial activity of each solvent used for extraction (ethanol and dichloromethane at $50 \mu \mathrm{l} / \mathrm{disk}$ ) was tested.

\section{Statistical analysis}

All experiments were carried out in triplicate and expressed as average of three analyses \pm standard deviation and Excel 2013 was used.

\section{Results and Discussion}

\section{Phytochemicalscreening}

Qualitative analysis of the main biological active compounds revealed the occurrence of flavonoids, anthocyanins, phenols, carotenoids, amino acids and carbohydrates in aerial part of $C$. alatavicus (Table 1). The presence of flavonoids, phenols, carotenoids, carbohydrates and amine-containing compounds were found in bulb.

The results of quantitative analysis of some determined biological active compounds in different parts of $C$. alatavicus are given in Table 2.

The plant material of $C$. alatavicus has abundant presence of secondary metabolites such flavonoids, phenols, carotenoids. The carotenoids content was greater in aerial part $(9.8 \mathrm{mg} \%)$ than in bulbs $(0,9 \mathrm{mg} \%)$. Flavonoids are $1.50 \%$ in the powdered aerial part and $0.43 \%$ in the powdered bulbs. The results revealed that aerial part of plant contains more biological active substances that may have high biological activities.

Phytochemical constituents of this species insufficiently explored. Aerial part contains ascorbic acid and some glycosides. Presence and quantitative content of saponin, ascorbic acid, catechin, pectin and protopectin in bulb of $C$. alatavicus depends on vegetation period of the plant (Kukushkina and Sedelnikova, 2010). It was reported that high content of ascorbic acid in aerial part and in bulb is observed in summer and it twice decreases in autumn (Sedelnikova and Kukushkina, 2014). Some flavonoids such as derivatives of myricetin, quercetin and kaempferol have been identified by HPLC in flowers of C. alatavicus (Nørbæk et al., 2002).

\section{Totalphenolic content}

The antioxidant activity, radical scavenging capacity and TPC of $C$. alatavicus has not previously been published. The reason to determine TPC in the plant extracts are directed that phenolics are the main group of compounds acting as antioxidants or free radical scavengers.

Methods for assessment of total phenolic content and determination of their antioxidant capacity are mostly based on oxidizing-reducing properties, possibility of phenolic compounds functioning as reduction agents and offering hydrogen radical or electron (Stratil et al., 2007). The results on TPC of $C$. alatavicus extracts obtained using different solvents are presented in Table 3.
The different solvents showed different content of phenolic. The highest phenolic contents were obtained in ethanol and methanol extracts from aerial part (72.29; $62.37 \mathrm{mg} \mathrm{GAE} / \mathrm{g}$ extract, respectively). Ethanol and methanol extracts from bulb have shown higher amount of phenolic (43.65 and $36.06 \mathrm{mg} \mathrm{GAE} / \mathrm{g}$ extract, respectively) than water and dichloromethane extracts from aerial part and bulb (23.55 and 24.26; 14.49 and $13.69 \mathrm{mg} \mathrm{GAE} /$ g extract, respectively). Rahaiee et al. (2015) reported that solvent type has significant effects on the TPC of the saffron extracts and $80 \%$ ethanol extract of saffron had the highest amount of TPC than aqueous and methanol $(50 \%, 80 \%)$ extracts.

The different polarity of organic solvents influences to the efficiency of the extraction and the solubility of phenolic compounds. Previous study has shown that the phenolic compounds more extracted by ethanol and methanol than water and dichloromethane. Therefore, the lowest TPC was observed in water and dichloromethane extracts.

Table 1. Preliminary phytochemical screening of $C$. alatavicus

\begin{tabular}{ccc}
\hline Metabolites & Aerial part & Bulb \\
\hline Carbohydrates & + & + \\
Tannins & - & - \\
Saponins & - & - \\
Amino acids & + & + \\
\hline Alkaloids & - & - \\
Phenols & + & + \\
Carotenoids & + & + \\
Flavonoids & + & + \\
Anthocyanins & + & - \\
Coumarins & - & - \\
\hline
\end{tabular}

Note: + Presence; - Absence.

Table2. Quantitative contents of some biological active compounds of C. alatavicus

\begin{tabular}{ccc}
\hline Metabolites & Aerial part & Bulb \\
\hline Flavonoids & $1.50 \pm 0.09$ & $0.43 \pm 0.07$ \\
Carbohydrates & $0.05 \pm 0.01$ & $0.06 \pm 0.02$ \\
Amino acids & $7.49 \pm 1.20$ & $3.88 \pm 0.56$ \\
Carotenoids & $9.78 \pm 1.09$ & $0.91 \pm 0.28$ \\
\hline
\end{tabular}

Note: Values are expressed as g of the dry material (\%) except for carotenoids $(\mathrm{mg} \%)$, and all data are means $\pm \mathrm{SD} ;(\mathrm{n}=3)$.

Table 3. Total phenolic content of the extracts from different parts of $C$. alatavicus

\begin{tabular}{ccc}
\hline Extracts & Aerial part & Bulb \\
\hline Water & $24.26 \pm 0.43^{\mathrm{c}}$ & $14.49 \pm 0.29^{\mathrm{c}}$ \\
Methanol & $62.37 \pm 0.49^{\mathrm{b}}$ & $43.65 \pm 0.76^{\mathrm{a}}$ \\
Ethanol & $72.29 \pm 2.16^{\mathrm{a}}$ & $36.06 \pm 0.43^{\mathrm{b}}$ \\
Dichloremethane & $23.55 \pm 2.15^{\mathrm{c}}$ & $13.63 \pm 0.43^{\mathrm{c}}$ \\
\hline
\end{tabular}

Note: Values are expressed as mg GAE/g extract; different superscript letters within column are significantly different at $\mathrm{p}<0.01$ (values are from high to low).

Table 4. Total antioxidant activity $(\% \pm S D)$ of $C$. alatavicus extracts and standard by the $\beta$-carotene bleaching method

\begin{tabular}{ccc}
\hline Extracts/Standard & Aerial part & Bulb \\
\hline Water & $33.57 \pm 1.17^{\mathrm{c}}$ & $27,38 \pm 0.16^{\mathrm{c}}$ \\
Methanol & $46.13 \pm 0.25^{\mathrm{b}}$ & $37,55 \pm 1.51^{\mathrm{a}}$ \\
Ethanol & $61.34 \pm 0,58^{\mathrm{a}}$ & $30.03 \pm 0,62^{\mathrm{b}}$ \\
Dichloromethane & $26.66 \pm 3,12^{\mathrm{d}}$ & $17.21 \pm 0,48^{\mathrm{d}}$ \\
BHT & \multicolumn{2}{c}{$91.4 \pm 1.19$} \\
\hline
\end{tabular}

Note: Different superscript letters within column are significantly different at $\mathrm{p}<0.05$ (values are from high to low). 
346

\section{Total antioxidant activity}

The $\beta$-carotene bleaching test is based on the loss of the yellow colour of $\beta$-carotene due to its reaction with radicals which are formed by linoleic acid oxidation in an emulsion (Kulisic et al., 2004). Table 4 shows the potential of $C$. alatavicus extracts and standard (BHT) to inhibit lipid peroxidation as evaluated by the bleaching of $\beta$-carotene.

The highest TAA was determined in ethanol extract from aerial part (61.34\%). Methanol, water and dichloromethane extracts have shown middle and low TAA $(46.13 \% ; 33.57 \%$ and $26.66 \%)$. It is statistically significant $(\mathrm{p}<0.05)$. Bulb methanol extract showed higher AA (37.55\%) than water and dichloromethane extracts (27.38\% and $17.21 \%$ ). All the extracts showed low TAA against synthetic standard BHT (91.4\%).

\section{Radicalscavenging activity}

The DPPH test is based on the ability of the stable DPPH free radical to react with hydrogen donors. In this test, a solution of radical is decolourized after reduction with an antioxidant or a radical (Parejo et al.,2000).

The results of the experiments also indicated that ethanol extracts of $C$. alatavicus have the high free radical scavenging activity. The comparable free radical scavenging rates of the extracts at the concentration of $500 \mathrm{\mu g} / \mathrm{ml}$ are shown in Fig. 1 .

The highest scavenging activity was observed in ethanol extracts from aerial part and bulb (65.5\% and 54.08\%). Methanol extracts showed lower inhibitory activity (48.73\% and $35.04 \%)$, but higher than activity of dichloromethane extracts (17.9\% and $13.9 \%$, respectively).

The $\mathrm{IC}_{50}$ value is one of the important parameter in determination of antioxidant capacity. $\mathrm{IC}_{50}$ value was determined from the plotted graph of scavenging activity against various concentrations of the extracts. $\mathrm{IC}_{50}$ values of $C$. alatavicus extracts were calculated to compare the antioxidant activity and listed in Table 5.

The lowest IC so $_{0}$ indicated the strongest ability of the extracts to act as DPPH radicals scavengers. Out of the all extracts minimum IC S0 $_{50}(387 \mu \mathrm{g} / \mathrm{ml})$ was determined in ethanol extract from aerial part. Dichloromethane and water extracts showed the high $\mathrm{IC}_{50}$ values (from 801 to $3,221 \mathrm{\mu g} / \mathrm{ml}$ ). Antiradical activities of commercial antioxidants of vitamin $\mathrm{C}$ and Trolox were higher $\left(\mathrm{IC}_{50} 26.35\right.$ and $\left.37.16 \mathrm{\mu g} / \mathrm{ml}\right)$.

The results obtained in this study show that DPPH scavenging activity of $C$. alatavicus is less than $C$. sativus, but higher than other species of Crocus as compared to the published experimental data. So, $\mathrm{IC}_{50}$ value of $C$. sativus ranged from 231.75 to $210.79 \mu \mathrm{g} / \mathrm{ml}$ for methanol extract, $255.44 \mu \mathrm{g} / \mathrm{ml}$ for water extract and $299.4 \mathrm{\mu g} / \mathrm{ml}$ for ethanol extracts (Karimi et al., 2010; Sariri et al., 2011). Whereas methanol extracts of $C$.

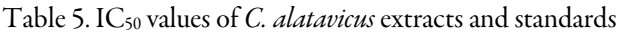

\begin{tabular}{ccc}
\hline Part of plant & Extracts & $\mathrm{IC}_{50}(\mu \mathrm{g} / \mathrm{ml})$ \\
\hline \multirow{3}{*}{ Aerial part } & Water & 865 \\
& Methanol & 510 \\
& Ethanol & 387 \\
& Dichloromethane & 926 \\
Bulb & Water & 801 \\
& Methanol & 853 \\
Vitamin C & Ethanol & 443 \\
Trolox & Dichloromethane & 3,221 \\
\hline
\end{tabular}

baytopiorum, C. flavus, C. biflorus showed $78.21 \%, 90.51 \%$ and $76.52 \%$ radical scavenging activity at $1.6 \mathrm{mg} / \mathrm{ml}$ concentration (Acar et. al., 2010). Trice less concentration of ethanol extracts from different part of C. alatavicus initiate activity about $65.5 \%$ and $54.98 \%$ in this study.

\section{Antibacterial activity}

The various extracts from $C$. alatavicus showed selective and varying degree of activity against different bacteria. The results of the zone inhibition determined by the disk diffusion method are presented in Table 6.

It is clear from the results that all tested bacterial strains were susceptible at $20 \mu \mathrm{l}$ concentration of antibiotic kanamycin. Among the solvents, ethanol at $50 \mu \mathrm{l}$ showed antibacterial activity against strains of E. coli, B. subtilis and B. cereus, but did not show activity against stains of St. aureus. Dichloromethane was low effective only against $E$. coli with $13.08 \mathrm{~mm}$ diameter zone of inhibition. Plant extracts exhibited selective activity against different bacteria; did not show activity against gramnegative bacteria $E . c o l i$, but were effective against gram-positive $S$. aureus, B. subtilis and B. cereus. Ethanol extracts with a high phenolic content showed a high inhibition activity. In addition, ethanol extract from aerial part at $50 \mu \mathrm{l}$ concentration showed antibacterial activity against $B$. subtilis, $B$. cereus and $S$. aureus. Diameter of zone inhibition ranged from $17.32-21.72 \mathrm{~mm}$, compared to control (70\% ethanol) $10 \mathrm{~mm}$. Minimal concentration of the extract $(25 \mu \mathrm{l})$ did not show activity against all test-cultures. Ethanol extract from bulb was effective against $B$. subtilis and $B$. cereus at all tested concentrations. Diameter of zone inhibition ranged from 15.66 to $20.67 \mathrm{~mm}$. Water and dichloromethane extracts with a low phenolic content were not effective against all the tested bacteria. Dichloromethane extract from bulb showed antibacterial activity against only $B$. cereus at $25 \mu \mathrm{l}$ concentration (zone of inhibition $-20.03 \mathrm{~mm}$ ). It has been reported that aqueous extracts of saffron onion at different concentration also have not antibacterial activity against $B$. anthracis, $S$. enteritidis, $S$. aureus, Proteus, E. coli by the disk diffusion test (Soureshjan and Heidari, 2014). Aqueous extract of C. sativus also showed least activity, but hexane and methanol extracts showed a promising antibacterial activity (Hussain et al., 2014).

The results of this study reveal selective antibacterial activity of ethanol extracts of $C$. alatavicus with a high phenolic content against gram-positive bacteria S. aureus, B. subtilis and B. cereus.

\section{Conclusions}

The results obtained by the phytochemical screening of $C$. alatavicus revealed the predominant content of secondary metabolites in aerial part of the plant. The highest TPC and DPPH-radical scavenging activity and TAA were detected in ethanol and methanol extracts. These results indicated that antioxidant activities $C$. alatavicus are correlated with the amount of phenolic in the plant extracts. Ethanol extract from aerial part compared to the other extracts is the most effective against tested gram-positive strains. Hence, $C$. alatavicus growing in Kazakhstan area may be considered for accessible source of natural active compounds with antioxidant properties as well as antimicrobial activity. Further studies will be done to develop the effective methods of in vitro propagation of the valuable endemic species of crocus. 
Table 6. Antimicrobial activity of the various extracts from $C$. alatavicus

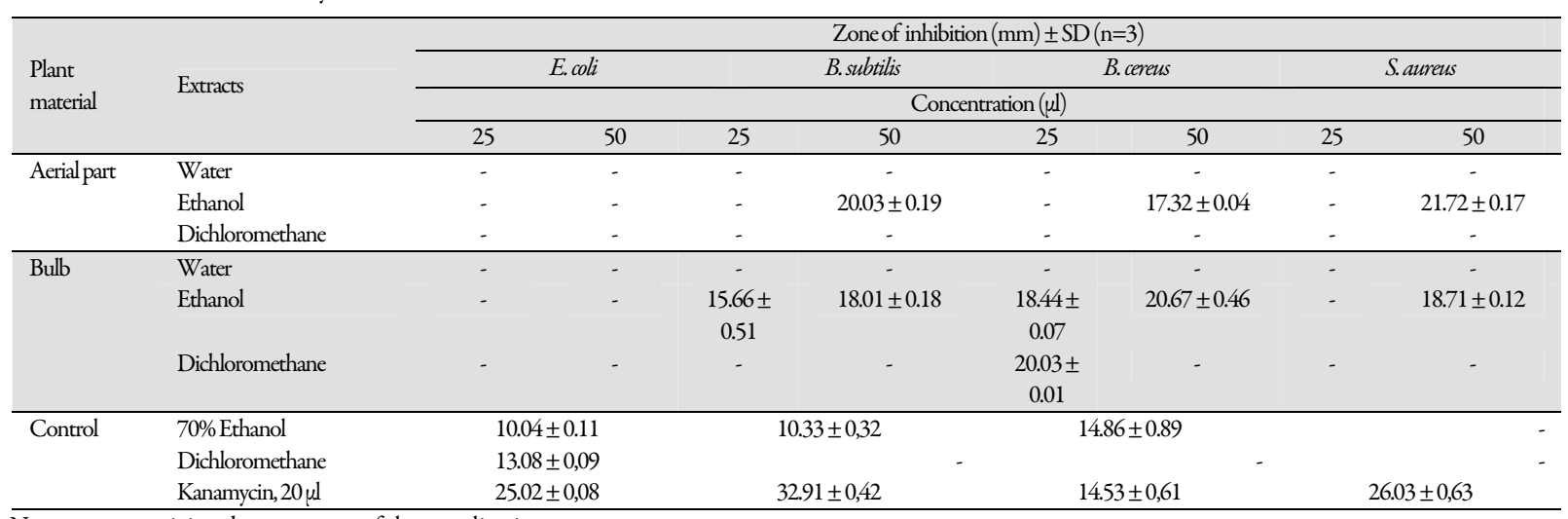

Note: $-=$ no activity; data are mean of three replications

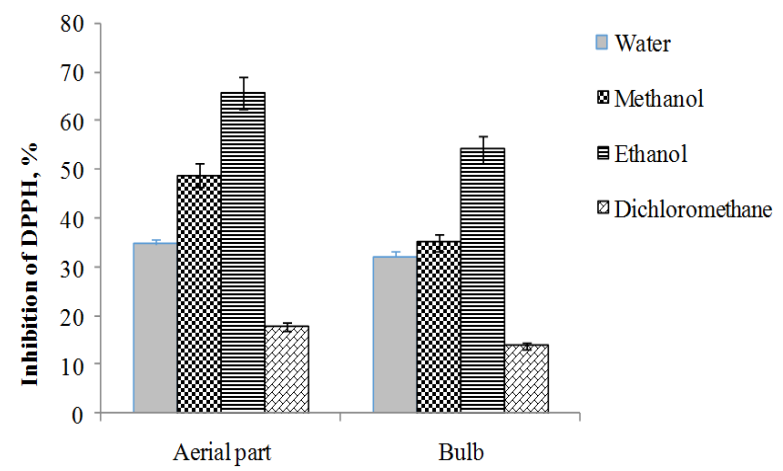

Fig. 1. Scavenging effect of $C$. alatavicus extracts at $500 \mu \mathrm{g} / \mathrm{ml}$ on DPPH radicals

\section{Acknowledgments}

This work was supported by the Institute of Plant Biology and Biotechnology (grant number N0113 PK00272) and Al-Farabi KazNU as a part of training programs for doctoral students.

\section{References}

Acar G, Dogan NM, Duru ME, Kivrak I (2010). Phenolic profiles, antimicrobial and antioxidant activity of various extracts of Crocus species in Anatolia. African Journal of Microbiology Research 4(11):1154-1161.

Agnihotri VK (2015). Crocus sativus Linn: An Informative Review. Aperito Journal of Advanced Plant Biology 1(1):1-29.

Baba SA, Malik AH, Wani ZA, Mohiuddin T, Shah Z, Abbas N, Ashraf N (2015). Phytochemical analysis and antioxidant activity of different tissue types of Crocus sativus and oxidative stress alleviating potential of saffron extract in plants, bacteria, and yeast. South African Journal of Botany 99:80-87.

Baytenov MS (2001). Flora Kazakhstana [Flora of Kazakhstan]. Gylym, Alma-Ata.

Bhargava VK (2011). Medicinal uses and pharmacological properties of Crocus sativus Linn (Saffron). International Journal of Pharmacy and Pharmaceutical Sciences 3(3):22-26.
Chryssanthi DG, Lamari FN, Iatrou G, Pylara A, Karamanos NK, Cordopatis P (2007). Inhibition of breast cancer cell proliferation by style constituents of different Crocus species. Anticancer Research 27:357-362.

Duke JA, Ayensu EE (1985). Medicinal plants of China. Reference Publications, Algona.

Egamberdieva D, Mamadalieva N, Khodjimatov O, Tiezzi A (2012). Medicinal Plants from Chatkal Biosphere Reserve Used for Folk Medicine in Uzbekistan. Medicinal and Aromatic Plant Science and Biotechnology 7(1):56-64.

Ferrara L, Naviglio D, Gallo M (2014). Extraction of Bioactive Compounds of Saffron (Crocus sativus L.) by Ultrasound Assisted Extraction (UAE) and by Rapid Solid-Liquid Dynamic Extraction (RSLDE). European Scientific Journal 10(3):1-13.

Golmohammadi F (2014). Saffron and its Farming, Economic Importance, Export, Medicinal characteristics and Various Uses in South Khorasan Province - East of Iran. International Journal of Farming and Allied Sciences 3(5):566-596.

Golovkin BN, Rudenskaya RN, Trofimova IA, Shreter AI (2001). Biologicheskie aktivnye veshestva rastitelnogo proiskhozhdeniya [Biologically active substances of plant origin]. Nauka (2nd Ed), Moscow.

Harborne JB (1984). Phytochemical methods. Chapman and Hall (2nd Ed), London, NewYork.

Harpke D, Meng S, Kerndorff H, Rutten T, Blattner FR (2013). Phylogeny of Crocus (Iridaceae) based on one chloroplast and two nuclear loci: ancient hybridization and chromosome number evolution. Molecular Phylogenetics and Evolution 66(3):617-627.

Hosseinzadeh H, Nassiri-Asl M (2013). Avicenna's (Ibn Sina) the canon of medicine and saffron (Crocus sativus): A review. Phytotherapy Research 27:475-483.

Hussain S, Haq A, Nisar M, Ahmad T, Bhardwaj P (2014). Evaluation of In-vitro Anti-Mycobacterial Activity and Isolation of Active Constituents from Crocus sativus $\mathrm{L}$. (Iridaceae). Asian Journal of Medical and Pharmaceutical Researches 4(2):130-135. 
348

Ivaschenko AA (2005). Tulips and other bulbs plants of Kazakhstan. Printing house "Two Capitals", Almaty.

Kamenetsky R, Okubo H (2013). Ornamental geophytes: from basic science and to sustainable production. CRC Press, New York.

Karimi E, Oskoueian E, Hendra R, Hawa ZE Jaafar (2010). Evaluation of Crocus sativus L. stigma phenolic and flavonoid compounds and its antioxidant activity. Molecules 15:62446256.

Kukushkina TA, Sedelnikova LL (2010). Dinamika nakopleniya zapasnykh veshestv v klubnelukovisakh Crocus alatavicus i Gladiolus hybridus [Dynamic of accumulation of reserve substances in bulbs of Crocus alatavicus and Gladiolus bybridus]. Chemistry of Plant Raw Materials 2:123-126.

Kulisic T, Radonic A, Katalinic V, Milos M (2004). Use of different methods for testing antioxidative activity of oregano essential oil. Food Chemistry 85:633-640.

Monte CD, Bizzarri B, Gidaro MC, Carradori S, Mollica A, Luisi G, Granese A, Alcaro S, Costa G, Basilico N, Parapini S, Scaltrito MM, Masia C, Sisto F (2015). Bioactive compounds of Crocus sativus $\mathrm{L}$. and their semi-synthetic derivatives as promising anti-Helicobacter pylori, anti-malarial and antileishmanial agents. Journal of Enzyme Inhibition and Medicinal Chemistry 30(6):1027-1033.

Nørbæk R, Brandt K, Nielsen JK, Ørgaard M, Jacobsen N (2002). Flower pigment composition of Crocus species and cultivars used for a chemotaxonomic Investigation, Biochemical Systematics and Ecology 30:763-791.

Parejo L, Codina C, Petrakis C, Kefalas P (2000). Evaluation of scavenging activity assessed by Co (II)/EDTA-induced luminol chemiluminescence and DPPH center dot (2.2diphenyl-1-picrylhydrazyl) free radical assay. Journal of Pharmacological and Toxicological Methods 44:507-512.

Parray JA, Kamili AN, Hamid R, Reshi ZA, Qadri RA (2015). Antibacterial and antioxidant activity of methanol extracts of Crocus sativus L. c.v. Kashmirianus. Frontiers in Life Science 8(1):40-46.

Pintado C, Alicia de Miguel, Acevedo O, Nozal L, Novella JL, Rotger R (2011). Bactericidal effect of saffron (Crocus sativus L.) on Salmonella enterica during storage. Food Control 22:638-642.

Rahaiee S, Hashemi M, Moini S, Abbas Shojaosadati S, Razavi SH (2015). Comparison of phytochemical constituents and antioxidant activities of aqueous and alcoholic extracts of saffron. Quality Assurance and Safety Crops and Foods 7(4):521-529.

Rezaee R, Hosseinzadeh H (2013). Safranal: from an aromatic natural product to a rewarding pharmacological agent. Iranian Journal of Basic Medical Sciences 16(1):12-26.

Samarghandian S, Borji A (2014). Anticarcinogenic effect of saffron (Crocus sativus L.) and its ingredients. Pharmacognosy Research 6(2):99-107.
Sanja SD, Sheth NR, Patel NK, Patel D, Patel B (2009). Characterization and evaluation of antioxidant activity of Portulaca oleracea. International Journal of Pharmacy and Pharmaceutical Sciences 1(1):74-84.

Sariri R, Sabbaghzadeh R, Poumohamad F (2011). In-vitro antioxidant and anti-tyrosinase activity of methanol extracts from Crocus sativus flowers. Pharmacologyonline 2:12051215.

Saxena RB (2015). Botany, Taxonomy and cytology of Crocus orientales-series. Asian Journal of Science and Technology 6(5):1406-1410.

Sedelnikova LL, Kukushkina TA (2014). O soderzhanii askorbinovoi kisloty i saponinov u dekorativnykh rastenii [Ascorbic acid and saponin contents of ornamental plants]. In: Bazarnova NG, Markyna BI (Eds). Proceedings of the 6th All-Russian Conference on new advances in chemistry and chemical technology of plant raw materials. Publishing house of the Altai State University, Barnaul, Russia pp 287-239.

Simbar M, Shadipour M, Salamzadeh J, Ramezani-Tehrani F, Nasiri N (2015). The combination of "Pimpinella anisum, Apium graveolens and Crocus sativus (PAC)" is more effective than "mefenamic acid" on postpartum after-pain. Journal of herbal medicine 5:20-25.

Singh B, Sahu PM, Sharma MK (2002). Anti-inflammatory and antimicrobial activities of triterpenoids from Strobilanthes callosus Nees. Phytomedicine 9(4):355-359.

Soureshjan EH, Heidari M (2014). In vitro variation in antibacterial activity plant extracts on Glaucium elegans and saffron (Crocus sativus). Bangladesh Journal of Pharmacology 9:275-278.

Stratil P, Klejdus B, Kuban V (2007). Determination of phenolic compounds and their antioxidant activity in fruits and cereals. Talanta 71:1741-1751.

Tokgun O, Akca H, Mammadov R, Aykurt C, Deniz G (2012). Convolvulus galaticus, Crocus antalyensis and Lilium candidum extracts show their Antitumor activity through induction of p53-mediated apoptosis on human breast cancer cell line MCF-7 Cells. Journal of Medicinal Food 15(11):1000-1005.

Türkoğlu S, Çelik S, Türkoğlu I, Çakılcıŏlu U, Bahşi M (2010). Determination of the antioxidant properties of ethanol and water extracts from different parts of Teucrium parviflorum Schreber. African Journal of Biotechnology 9(40): 6797-6805.

Wettasinghe M, Shahidi F (1999). Antioxidant and free radical scavenging properties of ethanolic extracts of defatted borage (Borago officinalis L.) seeds. Food Chemistry 67:399-414.

Zhang Y, Tan D (2009). Breeding system and pollination biology of Crocus alatavicus (Iridaceae) geocarpic subalpine plant of the western Tianshan Mountain. Biodiversity Science 17(5):468-475. 